\title{
Chemical composition and antimicrobial activity of Thymus pannonicus All. (Lamiaceae) essential oil
}

Research Article

\author{
Zoran Maksimović ${ }^{1 *}$, Marina Milenkoviće ${ }^{2}$ Dragana Vučićević ${ }^{2}$ Mihailo Ristić ${ }^{3}$ \\ 1 Institute of Pharmacognosy, School of Pharmacy, \\ University of Belgrade, \\ 11221 Belgrade, Serbia \\ ${ }^{2}$ Institute of Microbiology and Immunology, School of Pharmacy, \\ University of Belgrade, \\ 11221 Belgrade, Serbia \\ ${ }^{3}$ Institute for Medicinal Plant Research „Dr Josif Pančić“, \\ 11000 Belgrade, Serbia
}

Received 14 December 2007; Accepted 7 February 2008

Abstract: This paper presents the results of a study on chemical composition and antimicrobial activity of Thymus pannonicus All. (Lamiaceae) essential oil from Vojvodina province (north of Serbia). The investigated oil was hydrodistilled from a flowering plant and analysed by GC and GC-MS. Fifty-three constituents were identified (>97\% of total oil), with geranial $(41.42 \%, \mathrm{w} / \mathrm{w})$ and neral $(29.61 \%$, w/w) as the most prominent. The antimicrobial activity of the oil was evaluated using agar disc diffusion and broth microdilution method against Staphylococcus aureus, Enterococcus faecalis, Pseudomonas aeruginosa, Escherichia coli, two strains of Klebsiella pneumoniae and two strains of Candida albicans. The essential oil exhibited antimicrobial activity to varying degrees against all tested strains. The maximum activity of $T$. pannonicus oil was observed against $E$. coli, $S$. aureus and both tested strains of $C$. albicans (MIC $=50 \mu l / m l$, each). Moderate activity was observed against $P$. aeruginosa and one of the tested strains of $K$. pneumoniae $(\mathrm{MIC}=200 \mu \mathrm{l} / \mathrm{ml})$, while $E$. faecalis and the other strain of $K$. pneumoniae expressed a higher degree of resistance (MIC $>200 \mu \mathrm{l} / \mathrm{ml}$ ). This study confirms that essential oil of $T$. pannonicus possesses remarkable in vitro antimicrobial activity against several medicinally important pathogens. This is attributable to lemon-scented citral, a mixture of geranial and neral, which has well-documented antimicrobial activity against a range of bacteria and fungi.

Keywords: Thymus pannonicus • Essential oil composition • Antimicrobial activity • Geranial • Neral

(c) Versita Warsaw and Springer-Verlag Berlin Heidelberg.

\section{Introduction}

Besides flavouring, aromatic plants have been used for their medicinal properties for centuries [1]. With respect to this subject, several consistent lines of evidence that essential oils are among the most important active constituents of herbs and spices have been generated over the past. As natural products with well documented and repeatedly demonstrated efficiency against a wide range of microorganisms, essential oils receive particular attention as agents suitable for prophylactic and medical treatment $[1,2]$.

\footnotetext{
*E-mail: zoran.maksimovic@pharmacy.bg.ac.yu
}

It is estimated that the genus Thymus comprises at least 200 species, with many subspecies, varieties, subvarieties and forms, endemic and widespread, distributed over Europe, Asia, North Africa and the Canary Islands [3-5]. Thymus species are used as medicinal and aromatic plants, as well as in cosmetics and perfumery, throughout their range. Most aspects of their medicinal use are related to the essential oil which contains various levels of thymol and/or carvacrol, phenolic derivatives with strong and wide-spectrum antimicrobial activity [1,6-8]. Species such as Thymus vulgaris L., Thymus zygis Loefl. ex L. and Thymus serpyllum L. sensu lato are the biological sources of herbal drugs 
Thymi herba, Thymi aetheroleum and Serpylli herba, officially recognised in many modern pharmacopoeias e.g. European Pharmacopoeia 6.0 [9].

Thymus pannonicus All. (Hungarian or Eurasian Thyme) is a perennial herbaceous plant, distributed in central and eastern Europe as well as in Russia, over open dry meadows, grasslands and rocks [3,4]. In Serbia, it can be found in Vojvodina province (mostly over southern slopes of Mt Vršačke planine, the outskirts of the Deliblato Sand and neighbouring regions), as well as in eastern, southeastern and central parts of the country (Mts Stara planina and Rudnik). This plant species contributes to several xerothermous grass formations $[10,11]$. In scientific literature, the grass association that developed on Mt Vršačke planine, in particular, has been described as a dry sub-continental silicate prairie-like grass formation, with prevalence of Agrostis spp [11]. In ecological terms, that formation developed on warm, dry silicate terrains at altitude above $160 \mathrm{~m}$, mostly over plains or mild slopes, on acidic soils derived from crystalline albite-muscovite schist and gneisslike granite $[11,12]$.

In southern Banat, where Mt Vršačke planine is situated, the dried herb of $T$. pannonicus is used to make tasty and refreshing herbal tea drinks, owing to its peculiar and pleasant lemon-like scent. Fresh leaves are used for aromatisation of homemade jams, candies and similar confections. It has also been taken with positive results for coughs and other respiratory complaints, as well as some cases of gastrointestinal disorder (personal communication with local people). Although such anecdotal evidence exists, scientific study about the aspects of therapeutic use of $T$. pannonicus, or its chemical inventory, remains scarce and inconsistent.

The aims of this investigation were: (i) to assess the antimicrobial activity of T. pannonicus essential oil, (ii) to determine its chemical composition, and (iii) to use these and previously published data to deduce which components are likely to contribute to observed activity.

\section{Experimental Procedures}

The herb of T. pannonicus was collected during the fullflowering stage (in June 2005) at locus typicus (Široko bilo locality at Mt Vršačke planine, the most prominent relief aggregate in southern part of the Pannonian lowland). Marijan Niketić, M. Sc., custodian of the Museum of Natural History in Belgrade, confirmed the identification of the plant material based on a voucher specimen deposited there. Plant material was dried at room temperature prior to hydrodistillation in a Clevenger apparatus, according to Procedure I of Pharmacopoea Jugoslavica IV [13].
GC analysis was carried out on a Hewlett Packard 5890 II gas chromatograph equipped with FID, a splitsplitless injection system (split ratio 1:30) and a 25 $\mathrm{m} \times 0.32 \mathrm{~mm}$ HP-5 fused silica capillary column (film thickness: $0.52 \mu \mathrm{m})$. Carrier gas was $\mathrm{H}_{2}$, with flow rate of $1 \mathrm{ml} / \mathrm{min}$. Oven temperature was programmed from $40^{\circ} \mathrm{C}$ to $280^{\circ} \mathrm{C}$ at $4^{\circ} \mathrm{C} / \mathrm{min}$ linear rate; injector and detector temperatures were maintained at $250^{\circ} \mathrm{C}$ and $280^{\circ} \mathrm{C}$, respectively. Injection volume: $1 \mu \mathrm{l}$ of $1 \%(\mathrm{w} / \mathrm{v})$ essential oil in ethanol.

GC-MS analyses was performed on a Hewlett Packard G 1800 C GCD Series II (GC-EID), fitted to a 30 $\mathrm{m} \times 0.25 \mathrm{~mm}$ HP- 5 MS capillary column (film thickness: $0.25 \mu \mathrm{m})$, using $\mathrm{He}(1 \mathrm{ml} / \mathrm{min})$ as a carrier gas under the temperature programme $40-260^{\circ} \mathrm{C}$, at $4^{\circ} \mathrm{C} / \mathrm{min}$ rate. Injector and detector temperatures were maintained at 250 and $260^{\circ} \mathrm{C}$, respectively. The components of the essential oil were identified by matching their mass spectra with published data [14] and libraries of mass spectra (Wiley and NIST/NBS). Experimental values for retention indices were determined using a calibrated Automated Mass Spectral Deconvolution and Identification System software (AMDIS version 2.1., DTRA/NIST, 2002).

Antibacterial and antifungal activities of $T$. pannonicus essential oil was assessed by agar disc diffusion [15], and broth microdilution method [16], using a panel of laboratory control strains obtained from the American Type Culture Collection (ATCC, Rockville, MD, USA) and National Collections of Industrial Food and Marine Bacteria (NCIMB Ltd, Aberdeen, UK). Antimicrobial activity of the tested oil was evaluated against Gram-positive bacteria Staphylococcus aureus (ATCC 25923) and Enterococcus faecalis (ATCC 29212), Gram-negative bacteria Escherichia coli (ATCC 25922), Pseudomonas aeruginosa (ATCC 27853) and two strains of Klebsiella pneumoniae (ATCC 29665 and NCIMB 9111), as well as two strains of yeast Candida albicans (ATCC 10259 and ATCC 24433).

Active cultures of microorganisms were prepared by transferring a loopful of cells from stock cultures to Müller-Hinton broth (MHB) for bacteria and Sabouraud dextrose broth (SDB - broth from The Institute for Immunology and Virology "Torlak", Belgrade, Serbia) for yeasts, and incubated without agitation for $24 \mathrm{~h}$ at $37^{\circ} \mathrm{C}$ and $25^{\circ} \mathrm{C}$, respectively. The cultures were diluted with fresh MHB and SDB to achieve optical densities corresponding to $2 \times 10^{6}$ colony forming units (CFU)/ml for bacteria and $2 \times 10^{5} \mathrm{CFU} / \mathrm{ml}$ for two strains of $C$. albicans.

Prior to analysis, the essential oil was dissolved in absolute ethanol to create two different concentrations $(2 \%$ and $4 \%, v / v)$. Different concentrations of the 
essential oil were used to determine whether a correlation between oil activity and its dose could be established. Sterile filter paper discs (6 $\mathrm{mm}$ in diameter) were individually impregnated with $20 \mu \mathrm{l}$ of the oil solution and placed onto agar previously inoculated with $100 \mu \mathrm{l}$ of the suspension of tested microorganisms. Plates were incubated for $18 \mathrm{~h}$ at $37^{\circ} \mathrm{C}$ for bacteria and for $48 \mathrm{~h}$ at $26^{\circ} \mathrm{C}$ for $\mathrm{C}$. albicans. Readings were taken in quadruplicate, by measuring diameters of zones of inhibition in $\mathrm{mm}$. Antibiogram tablets (The Institute for Immunology and Virology "Torlak", Belgrade, Serbia) of Ampicillin (10 $\mu \mathrm{g} / \mathrm{tbl})$, Amikacin $(10 \mu \mathrm{g} / \mathrm{tbl})$, Cephotaxim (30 $\mathrm{\mu g} / \mathrm{tbl})$ and Nystatin (100 IU/tbl) were used as positive controls, and absolute ethanol as a negative control. Each assay in this experiment was repeated twice.

To determine the minimal inhibitory concentration (MIC) of the oil, broth microdilution method used. MHB (for bacterial strains) and SDB (for yeasts) were supplemented with polysorbate 80 (Tween $80^{\circledR}$ ) resulting in a final concentration of $0.5 \%(\mathrm{v} / \mathrm{v})$. Bacterial strains were cultured overnight at $37^{\circ} \mathrm{C}$ in $\mathrm{MHB}$, while C. albicans was cultured overnight at $30^{\circ} \mathrm{C}$ in SDB. The test strains were suspended in fresh medium resulting in a final density of $5 \times 10^{5} \mathrm{CFU} / \mathrm{ml}$ which was confirmed by viable counts. The T. pannonicus oil was dissolved in 1\% dimethyl sulfoxide (DMSO) and a serial doubling dilution of the oil, ranging from $200 \mu \mathrm{l} / \mathrm{ml}$ to $12.5 \mu \mathrm{l} / \mathrm{ml}$, was prepared in a 96 -well microtiter plate. The plates were incubated for $24 \mathrm{~h}$ at $37^{\circ} \mathrm{C}$ for the bacteria and for $48 \mathrm{~h}$ at $26^{\circ} \mathrm{C}$ for $\mathrm{C}$. albicans. The growth of microorganisms was indicated by the presence of a white "pellet" on the well bottom. MIC value is defined as the lowest concentration of investigated oil at which the microorganisms do not demonstrate visible growth. All determinations were performed in duplicate and growth controls consisting of MHB and SDB media with $1 \%$ (v/v) DMSO were included.

\section{Results and Discussion}

Air-dried plant material yielded $0.45 \pm 0.03 \%(\mathrm{v} / \mathrm{w})$ of yellow, pleasantly lemon-scented oil. GC and GC-MS analyses of $T$. pannonicus essential oil resulted in the identification of 53 compounds, representing $97.54 \%$ of the oil, the majority of which belong to the class of terpenoids. All components are listed in Table 1, in order of their elution. T. pannonicus oil was characterised by exceptionally high percentages of oxygenated monoterpenes (91.75\%). In particular, lemon-scented geranial and neral (the mixture of which is frequently referred to as citral) comprised $71 \%$ of the oil.
Structurally related monoterpenes such as nerol, nerol oxide, neryl acetate and geraniol, were present at much lower concentrations (below 3\%). The other classes of constituents included sesquiterpene and monoterpene hydrocarbons as well as oxygenated sesquiterpenes. These appear to be background constituents. Among the other terpenes of some importance were small quantities of linalool, $\alpha$-terpineol, $\beta$-caryophyllene, germacrene $D$ and $\beta$-bisabolene. Amounts of thymol, thymol methylether and carvacrol were also low.

In a survey of available literature, only a few publications relevant to the chemical composition of $T$. pannonicus were found, suggesting that a substantial dearth of information in this field still exists. A greater interest in this essential oil was expected as this species is neither endemic, nor endangered across the whole area of its distribution. According to Karuza-Stojaković et al., the principal constituents of $T$. pannonicus essential oil from southern parts of Vojvodina province were terpinyl acetate, terpinen-4-ol, thymol, carvacrol and geranyl acetate (listed in order of descending quantity) [17]. Recent comprehensive studies of chemical variability in hydrodistilled essential oils of different wild growing and cultivated populations of T. pannonicus from Hungary, as well as supercritical fluid extracts of various Lamiaceae species, confirmed that high concentrations of both thymol and p-cymene are the main chemosystematic attributes of $T$. pannonicus essential oil $[18,19]$.

Generally, a high variability and diversity is observed in the chemical composition of essential oils of Thymus species: at least 20 different chemotypes in the genus have been established thus far [20]. Furthermore, the production of phenolic compounds is favoured in warmer and drier climatic zones while other, non-phenolic compounds usually accumulate in higher quantities in colder and damper areas [21]. The low level of phenols in T. pannonicus essential oil, found in our study, seems to follow this pattern. Compared to essential oils of other Thymus species, the T. pannonicus oil used in our study was somewhat similar to oil of Thymus $x$ citriodorus (Pers.) Schreb., a putative hybrid between T. vulgaris $\mathrm{L}$. and $T$. pulegioides $\mathrm{L}$. This hybrid is rich in geraniol, and a geraniol/geranial/neral chemotype of $T$. pulegioides from Lithuania [21,22], indicating a possible chemosystematic kinship.

As shown in our results in Table 2, T. pannonicus essential oil had noteworthy antimicrobial potential against bacteria and yeasts, but there was no clear correlation between observed activity and the dose applied. Gram-positive bacteria are considered more sensitive to essential oils and plant extracts than Gramnegative ones. In our study, however, susceptibility of bacteria to T. pannonicus essential oil and the Gram 


\begin{tabular}{|c|c|c|c|}
\hline Compound & $\mathrm{Kl}^{\mathrm{a}}$ & $\mathrm{Kl}_{\exp }^{\mathrm{b}}$ & $\%$ \\
\hline$\alpha$-Pinene & 939 & 937 & 0.11 \\
\hline Camphene & 954 & 944 & 0.08 \\
\hline 1-Octen-3-ol & 979 & 986 & 0.57 \\
\hline 3-Octanone & 984 & 991 & 0.26 \\
\hline Octan-3-ol & 991 & 1001 & 0.10 \\
\hline$\alpha$-Phellandrene & 1003 & 1005 & 0.10 \\
\hline$\Delta 3$-Carene & 1011 & 1007 & 0.04 \\
\hline$\alpha$-Terpinene & 1017 & 1017 & 0.11 \\
\hline p-Cymene & 1025 & 1025 & 0.35 \\
\hline$\beta$-Phellandrene & 1030 & 1028 & 0.23 \\
\hline 1,8-Cineole & 1031 & 1031 & 0.67 \\
\hline trans- $\beta$-Ocimene & 1050 & 1048 & 0.05 \\
\hline$\gamma$-Terpinene & 1060 & 1056 & 0.07 \\
\hline Artemisia ketone & 1062 & 1062 & 0.40 \\
\hline cis-Sabinene hydrate & 1070 & 1068 & 1.33 \\
\hline trans-Linalool oxide (furanoid) & 1073 & 1073 & 0.07 \\
\hline$\alpha$-Terpinolene & 1089 & 1086 & 0.11 \\
\hline Linalool & 1097 & 1102 & 1.25 \\
\hline 1,3,8-p-Menthatriene & 1110 & 1109 & 0.31 \\
\hline Chrysanthenone & 1128 & 1125 & 0.12 \\
\hline$\beta$-Citronellol & 1128 & 1137 & 0.07 \\
\hline Chrysanthemol & 1140 & 1150 & 2.02 \\
\hline Nerol oxide & 1153 & 1156 & 1.34 \\
\hline cis-Chrysanthenol & 1164 & 1164 & 2.13 \\
\hline Borneol & 1169 & 1169 & 0.10 \\
\hline Rosefuran epoxide & 1177 & 1175 & 0.65 \\
\hline Terpinen-4-ol & 1177 & 1175 & 4.34 \\
\hline$\alpha$-Terpineol & 1189 & 1190 & 0.56 \\
\hline cis-Carveol & 1229 & 1203 & 0.07 \\
\hline
\end{tabular}

\begin{tabular}{l|lll}
\hline Nerol & 1230 & 1231 & 2.71 \\
Thymol methylether & 1235 & 1232 & 0.37 \\
Neral & 1238 & 1252 & 29.61 \\
Geraniol & 1253 & 1266 & 0.31 \\
Geranial & 1267 & 1284 & 41.42 \\
Lavandulyl acetate & 1290 & 1286 & 0.30 \\
Thymol & 1290 & 1298 & 0.89 \\
Carvacrol & 1299 & 1307 & 0.05 \\
Neryl acetate & 1362 & 1363 & 1.62 \\
$\alpha$-Copaene & 1377 & 1375 & 0.13 \\
$\beta$-Bourbonene & 1388 & 1380 & 0.75 \\
$\beta$-Caryophyllene & 1419 & 1417 & 0.29 \\
$\beta$-Gurjunene & 1434 & 1428 & 0.15 \\
$\alpha$-Humulene & 1455 & 1454 & 0.07 \\
allo-Aromadendrene & 1460 & 1459 & 0.07 \\
$\gamma$-Muurolene & 1480 & 1478 & 0.07 \\
Germacrene D & 1485 & 1480 & 0.43 \\
$\beta$-Bisabolene & 1506 & 1508 & 0.67 \\
$\delta$-Cadinene & 1523 & 1523 & 0.09 \\
Spathulenol & 1578 & 1576 & 0.26 \\
Caryophyllene oxide & 1583 & 1581 & 0.15 \\
$\beta$-Oplopenone & 1608 & 1611 & 0.13 \\
$\alpha$-Cadinol & 1654 & 1653 & 0.18 \\
Eudesma-4(15),7-dien-1 $\beta-0 l$ & 1688 & 1685 & 0.07 \\
Total & & & 97.54 \\
Monoterpene hydrocarbons & & & 1.56 \\
Oxygenated monoterpenes & & & 91.75 \\
Sesquiterpene hydrocarbons & & & 2.72 \\
Oxygenated sesquiterpenes & & & 0.79 \\
Others & & & 1.58 \\
\hline
\end{tabular}

Table 1. Chemical composition of Thymus pannonicus essential oil.

${ }^{a} \mathrm{Kl}=$ Kovats indices, retention indices relative to $C_{9}-C_{24}$-alkanes on the HP 5MS column.

${ }^{\circ} \mathrm{Kl} \mathrm{exp}_{\mathrm{O}}=$ Kovats indices, experimentally determined.

reaction appeared to have little, if any, influence on growth inhibition. Dorman and Deans [1] reported similar observations. The oil exhibited clear bacteriostatic effect against Escherichia coli, Staphylococcus aureus and Pseudomonas aeruginosa. This is particularly surprising for $P$. aeruginosa since it is known to possess high level of intrinsic resistance to a number of antimicrobial agents, attributable to a very restrictive outer membrane envelope. Enterococcus faecalis was found to be more resistant. In tests against Klebsiella pneumoniae, the oil expressed an unclear effect, since one of the tested strains appeared to be resistant while the other was markedly sensitive. T. pannonicus essential oil proved to be an effective fungistatic agent too, as both tested Candida albicans strains were found to be sensitive. The observed activity cannot be associated with the presence of phenolic constituents, as only low concentrations of thymol, its isomers and/or derivatives were detected. The results of chemical analysis indicate that antimicrobial effects of this oil should be accredited instead to lemonscented citral, a mixture of cis- and trans-isomers of 3,7-dimethyl-2,6-octadiene-1-al (geranial and neral, respectively), which has well-documented antimicrobial activity against a range of bacteria and fungi [1,23-27].

\section{Conclusions}

The present study is the first report of any kind on the activity of $T$. pannonicus in general, and its essential oil in particular. It is also one of only a few relevant studies dealing with the chemical composition of T. pannonicus 


\begin{tabular}{|c|c|c|c|c|c|c|c|c|}
\hline \multirow[t]{2}{*}{ Microbial species } & \multicolumn{7}{|c|}{ Diameters of inhibition zones $(\mathrm{mm})^{\mathrm{a}}$} & \multirow{2}{*}{$\begin{array}{l}\text { MIC } \\
(\mu \mathrm{l} / \mathrm{ml})\end{array}$} \\
\hline & $2 \%^{\mathrm{b}}$ & $4 \%^{\mathrm{b}}$ & Control $^{\mathrm{C}}$ & Ampicillin $^{d}$ & Amikacin $^{\text {d }}$ & Cephotaxime & Nystatin $^{\dagger}$ & \\
\hline Staphylococcus aureus (ATCC 25923) & $17.5 \pm 2.1^{\star \star}$ & $16.8 \pm 1.3^{\star \star}$ & $11.0 \pm 0.0$ & $35.0 \pm 7.0$ & $26.5 \pm 2.1$ & - & - & 50 \\
\hline Enterococcus faecalis (ATCC 29212) & $14.3 \pm 1.5$ & $14.5 \pm 2.1$ & $13.5 \pm 0.7$ & $16.0 \pm 0$ & - & - & - & $>200$ \\
\hline Escherichia coli (ATCC 25922) & $10.0 \pm 0.8^{* * *}$ & $12.0 \pm 0.0^{\star \star \star}$ & $5.0 \pm 0.0$ & $20.5 \pm 0.7$ & $20.0 \pm 0$ & $30.5 \pm 0.7$ & - & 50 \\
\hline Pseudomonas aeruginosa (ATCC 27853) & $19.5 \pm 1.0^{\star *}$ & $20.3 \pm 1.3^{\star \star}$ & $14.5 \pm 0.7$ & $10.0 \pm 0.0$ & $27.5 \pm 3.5$ & - & - & 200 \\
\hline Klebsiella pneumoniae (ATCC 29665) & $19.0 \pm 3.5$ & $22.8 \pm 1.3$ & $17.5 \pm 3.5$ & $22.0 \pm 5.0$ & - & - & - & $>200$ \\
\hline Klebsiella pneumoniae (NCIMB 9111) & $22.8 \pm 2.4$ & $31.5 \pm 2.5^{\star \star}$ & $20.5 \pm 3.5$ & $17.0 \pm 4.2$ & - & - & - & 200 \\
\hline Candida albicans (ATCC 24433) & $19.5 \pm 2.5^{\star}$ & $18.8 \pm 1.0^{*}$ & $12.5 \pm 3.5$ & - & - & - & $20.0 \pm 0$ & 50 \\
\hline Candida albicans (ATCC 10259) & $16.3 \pm 0.5^{\star \star \star}$ & $19.0 \pm 1.2^{\star \star \star}$ & $10.0 \pm 0.0$ & - & - & - & $20.0 \pm 0$ & 50 \\
\hline
\end{tabular}

Table 2. Antibacterial and antifungal activity of Thymus pannonicus essential oil.

${ }^{a}$ Results are given as mean $\pm S D$.

${ }^{b}$ Dilution of essential oil in absolute ethanol, v/v.

${ }^{*} p<0.05$, compared to control.

c Absolute ethanol.

** $p<0.01$, compared to control.

${ }^{d}$ Applied dose: $10 \mu \mathrm{g} / \mathrm{tb} /$.

e Applied dose: 30 mg/tbl.

' Applied dose: 100 U/tbl.

essential oil. The observed antimicrobial activity confirms anecdotal evidence of the effectiveness of traditional use of this herbal drug against various respiratory and gastrointestinal ailments, where such activity would be beneficial. We hope the presented results will contribute to knowledge about the chemistry of essential oils of Thymus species in general, and will shed some light on Thymus pannonicus in particular as a source of natural products with potential use in the pharmaceutical industry.

\section{References}

[1] Dorman H.J., Deans S.G., Antimicrobial agents from plants: antibacterial activity of plant volatile oils, J. Appl. Microbiol., 2000, 88, 308-316

[2] Cowan M., Plant products as antimicrobial agents, Clin. Microbiol. Rev., 1999, 12, 564-582

[3] Jalas J., Thymus L., in: Tutin T.G., Heywood V.H., Burges N.A., Moore D.M., Valentine D.H., Walters S.M., et al., Flora Europaea, Vol. 3, Cambridge University Press, Cambridge, 1972, 172-182

[4] Diklić N., Thymus L., In: Josifović M. (Ed.), Flora SR Srbije, Tome VI, Serbian Academy of Sciences and Arts, Belgrade, 1974, 475-509, (in Serbian)

[5] Morales R., Studies on the genus Thymus, Lamiales Newsletter, 1996, 4, 6-8

[6] Didry N., Dubreuil L., Pinkas M., Antibacterial activity of thymol, carvacrol and cinnamaldehyde alone or in combination, Pharmazie, 1993, 48, 301-304

[7] Didry N., Dubreuil L., Pinkas M., Activity of thymol, carvacrol, cinnamaldehyde and eugenol on oral bacteria, Pharm. Acta Helv., 1994, 69, 25-28

[8] Horváth Gy., Kocsis B., Botz L., Németh J., Szabó L.Gy., Antibacterial activity of Thymus phenols by direct bioautography, Acta Biol. Szeged., 2002, 46, 145-146

[9] European Pharmacopoeia, 6th edition. Council of Europe - European Directorate for the Quality of Medicines, Strasbourg, 2007

[10] Panjković-Matanović V., Biljnogeografska analiza flore Vršačkih planina, Matica Srpska, Novi Sad, 1989, (in Serbian)

[11] Lakušić D., Blaženčić J., Ranđelović V., Butorac B., Vukojičić S., Zlatković B., et al., Staništa Srbije priručnik sa opisima i osnovnim podacima, Ministry of Science and Environment Protection; Institute of Botany and Botanical Garden "Jevremovac", University of Belgrade, Belgrade, 2005, (in Serbian, http://habitat.bio.bg.ac.yu or http://www.ekoserb. sr.gov.yu/projekti/stanista/)

[12] Zeremski M., Geomorfologija Vršačkih planina, Matica Srpska, Novi Sad, 1985, (in Serbian)

[13] Farmakopeja SFRJ, Pharmacopoea Jugoslavica IV, Federal Institute for Health Protection, Belgrade, 1984, (in Serbo-Croatian)

[14] Adams R.P., Identification of essential oil component by gas chromatography/quadrupole mass spectrometry, Allured Publishing Corporation, Carol Stream, USA, 2001

[15] Acar J.F., Goldstein F.W., Disc susceptibility test, 
In: Lorian V. (Ed.), Antibiotics in laboratory medicine, Williams \& Wilkins, Baltimore, London, Los Angeles, Sydney, 1996, 1-52

[16] Candan F., Unlu M., Tepe B., Daferera D., Polissiou M., Sökmen A., et al., Antioxidant and antimicrobial activity of the essential oil and methanol extracts of Achillea millefolium subsp. millefolium Afan. (Asteraceae), J. Ethnopharmacol., 2003, 87, 215-220

[17] Karuza-Stojaković Lj., Pavlović S., Živanović P., Todorović B., Količina i sastav etarskih ulja različitih vrsta roda Thymus L., Arh. farm., 1989, 39, 105111, (in Serbian)

[18] Pluhár Zs., Héthelyi É., Kutta G., Kamondy L., Evaluation of environmental factors influencing essential oil quality of Thymus pannonicus All. and Thymus praecox Opiz, J. Herbs Spices Med. Plants, 2007, 3, 23-43

[19] Kutta G., Pluhár Zs., Sárosi Sz., Yield and composition of supercritical fluid extracts of different Lamiaceae species, Int. J. Hort. Sci., 2007, 13, 79-82

[20] Tepe B., Sokmen M., Akpulat H.A., Daferera D., Polissiou M., Sokmen A., Antioxidative activity of the essential oils of Thymus sipyleus subsp. sipyleus var. sipyleus and Thymus sipyleus subsp. sipyleus var. rosulans, J. Food Eng., 2005, 66, 447-454

[21] Ložienė K., Venskutonis P.R., Influence of environmental and genetic factors on the stability of essential oil composition of Thymus pulegioides, Biochem. Syst. Ecol., 2005, 33, 517-525
[22] Stahl-Biskup E., Holthuijzen J., Essential oil and glycosidically bound volatiles of lemon-scented thyme, Thymus $x$ citriodorus (Pers.) Schreb, Flavour Fragr. J., 1995, 10, 225-229

[23] Lis-Balchin M., Deans S.G., Bioactivity of selected plant essential oils against Listeria monocytogenes, J. Appl. Microbiol., 1997, 82, 759-762

[24] Díaz L.H., Jorge M.R., Actividad antimicrobiana de plantas que crecen en Cuba, Rev. Cub. Plant. Med., 2001, 2, 44-47, (in Spanish)

[25] Ohno T., Kita M., Yamaoka Y., Imamura S., Yamamoto T., Mitsufuji S., et al., Antimicrobial activity of essential oils against Helicobacter pylori, Helicobacter, 2003, 8, 207-215

[26] Nguefack J., Budde B.B., Jakobsen M., Five essential oils from aromatic plants of Cameroon: their antibacterial activity and ability to permeabilize the cytoplasmic membrane of Listeria innocua examined by flow cytometry, Lett. Appl. Microbiol., 2004, 39, 395-400

[27] Sartoratto A., Machado A.L.M., Delarmelina C., Figueira G.M., Duarte M.C.T., Rehder V.L.G., Composition and antimicrobial activity of essential oils from aromatic plants used in Brazil, Braz. J. Microbiol., 2004, 35, 275-280 